\title{
Renal clear cell sarcoma presenting as a spontaneous renal hematoma: A rare presentation
}

\author{
Zeynep Canan Ozdemir, ${ }^{1}$ Burcu Ayvaci, ${ }^{1}$ Yeter Duzenli Kar, ${ }^{1}$ Mehmet Oguzman, ${ }^{2}$ Mehmet Surhan Arda, ${ }^{3}$ \\ Mustafa Fuat Acikalin, ${ }^{4}$ Ozcan Bor ${ }^{1}$ \\ ${ }^{1}$ Department of Pediatric Hematology and Oncology, Eskisehir Osmangazi Universitiy Faculty of Medicine, Eskisehir, Turkey \\ 2Department of Pediatrics, Eskisehir Osmangazi Universitiy Faculty of Medicine,Eskisehir, Turkey \\ ${ }^{3}$ Department of Pediatric Surgery, Eskisehir Osmangazi Universitiy Faculty of Medicine, Eskisehir, Turkey \\ ${ }^{4}$ Department of Pathology, Eskisehir Osmangazi University Faculty of Medicine, Eskisehir, Turkey
}

\begin{abstract}
Clear cell sarcoma of the kidney (CCSK) is an uncommon renal neoplasm of childhood. It represents between $2 \%$ and $9 \%$ of all pediatric renal tumors, and generally arises before the age of 5 years. It often mimics other pediatric renal tumors. Presently described is the case of a 7-year-old girl who presented with complaints of vomiting and abdominal pain. Abdominal ultrasonography revealed a right renal mass, and the patient developed a renal hematoma a few hours after admission. The patient underwent a nephroureterectomy with a provisional diagnosis of Wilms tumor; however, histopathological examination of a specimen revealed CCSK. CCSK is similar to Wilms tumor in terms of the typical age of appearance and clinical and histopathological features, but the treatment method and prognosis are different. Therefore, the differential diagnosis is very important. This case was presented to draw attention to a rare presentation of clear cell sarcoma. CCSK should be kept in mind in the differential diagnosis of a renal mass.
\end{abstract}

Keywords: Clear cell sarcoma; child; hematoma; kidney.

$\mathrm{R}$ enal tumors are rare in childhood. They constitute $6 \%$ to $7 \%$ of all pediatric tumors. Wilms tumor is the most frequently seen among them [1]. Clear cell sarcoma of the kidney (CCSK) is the second most frequently seen tumor after Wilms tumor [2,3]. Renal cell carcinoma and rhabdoid tumor are less frequently seen tumors [1]. Clear cell sarcoma is a unilateral tumor arising from the renal medulla; it is known as pediatric tumor with a propensity to metastasize to bone. It is called clear cell cancer because the cytoplasm contains multi- ple vesicles. It has a tendency to penetrate the renal and perirenal vascular system $[4,5]$. It is an important clinical entity because it can be confused with Wilms tumor, but the treatment is completely different. Presented here is the case of a child with an initial diagnosis of suspected Wilms tumor who developed massive, nontraumatic bleeding. The postoperative histopathological examination of the nephrectomy specimen established the diagnosis of CCSK. This case is presented because of a distinctive presentation.

Received: February 22, 2017 Accepted: May 02, 2017 Online: January 18, 2018

Correspondence: Dr. Zeynep Canan OZDEMIR. Eskisehir Osmangazi Universitesi Tip Fakultesi, Pediatrik Hematoloji ve Onkoloji Bilim Dall, Eskisehir, Turkey.

Tel: +90222 2393979 e-mail: efecanan@yahoo.com

(c) Copyright 2018 by Istanbul Provincial Directorate of Health - Available online at www.northclinist.com 


\section{CASE REPORT}

A 7-year-old girl presented with complaints of abdominal pain and vomiting that had begun 2 days earlier. Anamnesis revealed that she had persistent pain on the right side of the abdomen, had experienced bilious vomiting 3 to 4 times a day, and there was no weight loss, fever, or history of trauma. Her physical examination findings were a body temperature of $37.2^{\circ} \mathrm{C}$, heart rate of $96 \mathrm{bpm}$, and arterial blood pressure of $110 / 80 \mathrm{mmHg}$. There was diffuse abdominal tenderness and a mass $4 \times 5$ $\mathrm{cm}$ in size was palpated in the right renal bed (Fig. 1). Other systemic examination results were within normal limits. The hematological parameters were reported as hemoglobin: $11.6 \mathrm{~g} / \mathrm{dL}$, hematocrit: $34 \%$, mean corpuscular volume: $83.3 \mathrm{fL}$, mean corpuscular hemoglobin: $27.7 \mathrm{pg}$, mean corpuscular hemoglobin concentration:

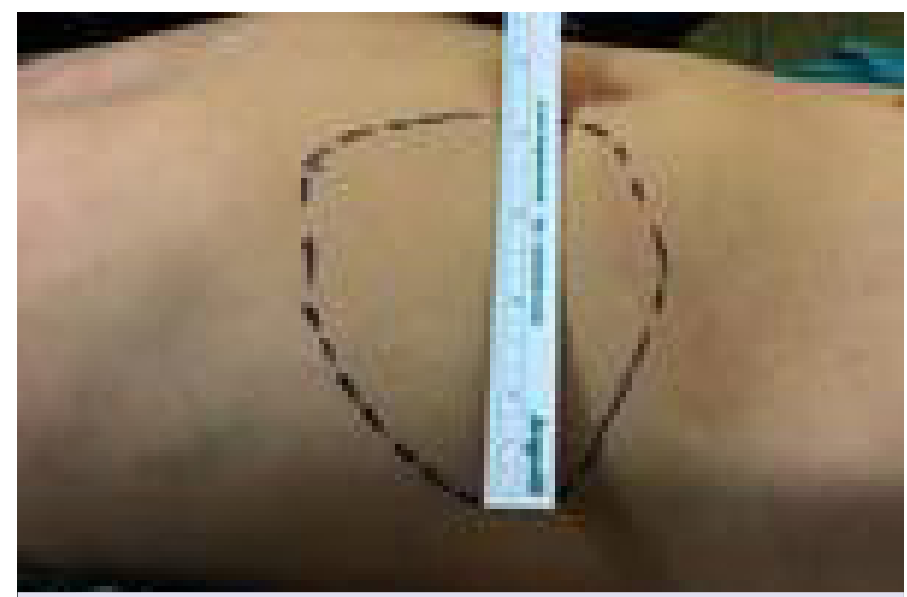

FIGURE1. The macroscopic appearance of the mass palpated on physical examination.

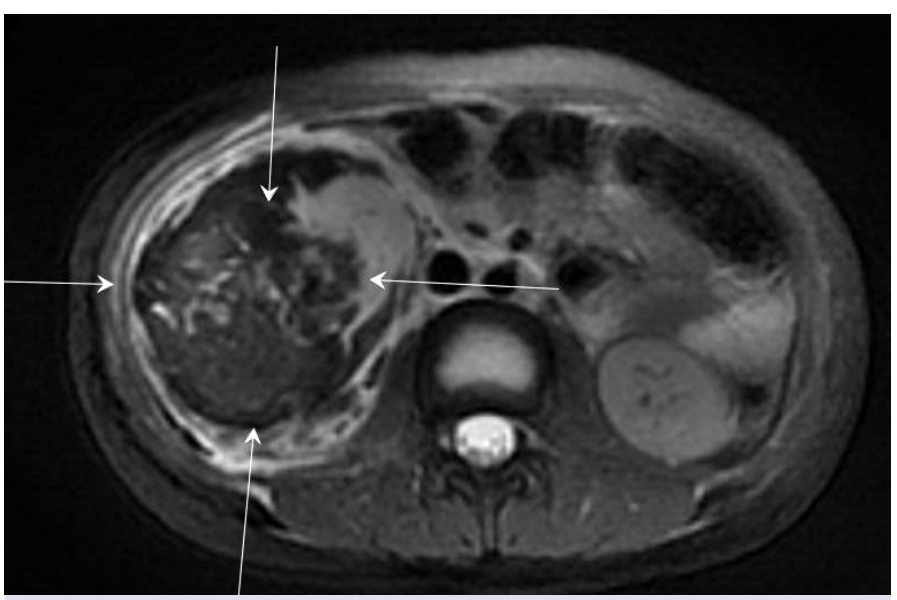

FIGURE 2. The abdominal tomography image of right renal mass and hematoma.
$33.2 \mathrm{mg} / \mathrm{dL}$, red cell distribution width: \%14.3, white blood cell count: $12800 / \mathrm{mm}^{3}$, platelet count: $347.000 /$ $\mathrm{mm}^{3}$, and C-reactive protein level: $0.314 \mathrm{mg} / \mathrm{dL}$. Results of hemochemistry and complete urinalysis were within normal limits. On abdominal ultrasound, an $8 \times 6.5-\mathrm{cm}$ mass lesion with predominant vascularization localized on the lower right kidney was detected. Doppler ultrasound did not reveal any thrombus in the renal vein or vena cava inferior. Her peak heart rate ranged between 110 and $120 \mathrm{bpm}$. In the sixth hour of hospitalization, her hemoglobin level dropped to $6 \mathrm{~g} / \mathrm{dL}$. Emergency abdominal computed-tomography was performed for suspected intratumoral bleeding and an erythrocyte suspension was infused. Abdominal tomography revealed a mass arising from the inferolateral end of the right kidney, not crossing the midline, and almost completely filling the perirenal fat capsule and the retroperitoneal region, with a predominant hemorrhagic component with indistinct borders (Fig. 2). The initial diagnosis was Wilms tumor. Emergency surgery was performed. The hematoma was drained and a right nephroureterectomy was performed (Fig. 3). Positron emission tomography and brain magnetic resonance imaging did not detect any evidence suggesting metastasis. The histopathological examination of a bone marrow biopsy specimen was unremarkable. The diagnosis of CCSK was made based on the histopathological result of nephrectomy specimen testing. Radiotherapy was performed on the tumor bed, and a combination chemotherapy consisting of doxorubicin, cyclophosphamide, etoposide, and vincristine was initiated. The chemotherapy treatment was continued for 6 months, and follow-up at 8 months revealed no further problem.

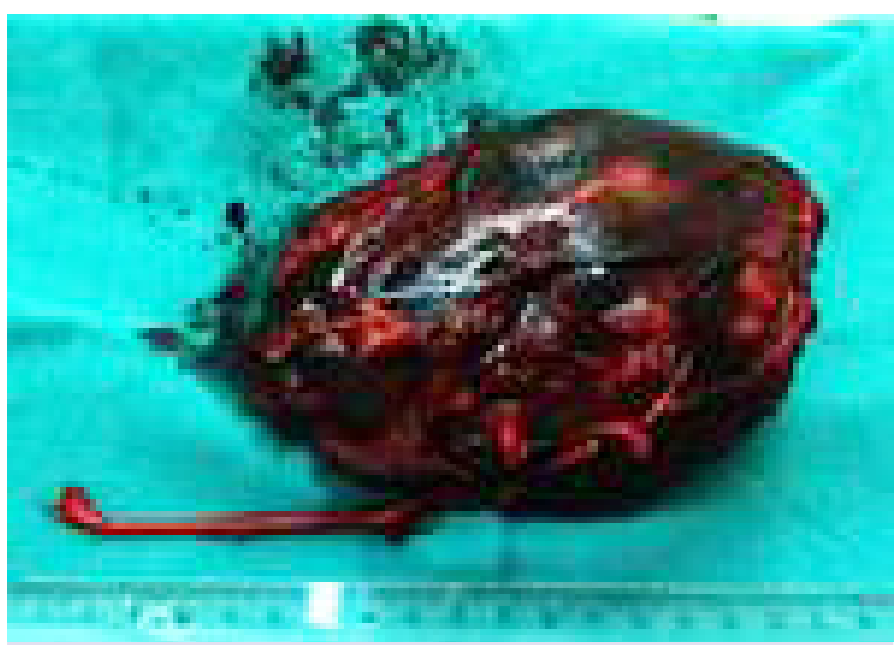

FIGURE 3. The macroscopic appearance of the mass. 


\section{DISCUSSION}

Wilms tumor makes up $92 \%$ of renal mass lesions. Of other renal tumors, $17 \%$ are clear cell sarcoma [2]. In a study of pediatric cases with clear cell sarcoma, it was reported that while the age of the patients ranged between 2 months and 14 years, nearly $50 \%$ of the patients were between 2 and 3 years of age at the time of diagnosis. It was also indicated that it is seen more frequently in male children, and has an overall survival rate of $69 \%$ [3]. Since there are no clinical or radiological findings specific to clear cell sarcoma, it is frequently confused with Wilms tumor, which complicates decision-making process for treatment $[4,6]$. The most frequently seen symptoms include abdominal mass, hematuria, and abdominal pain. Other symptoms defined include vomiting, fever, constipation, loss of appetite, and hypertension [7]. To our knowledge, there has been no prior report of a case of CCSK with a renal hematoma.

Wilms tumor typically metastasizes to the lymph nodes, lungs, or liver. Bone metastasis is rare. Clear cell sarcoma generally has a tendency to metastasize to the lymph nodes, bone, lungs, or liver [4]. Wilms tumor tends to invade blood vessels as tumor thrombi. These thrombi may be found in the renal veins, the vena cava inferior, or even the right atrium. In $4 \%$ to $10 \%$ of cases, tumor thrombi in a renal vein or the vena cava inferior can be seen at the time of diagnosis [8]. The precise incidence of vascular tumor thrombosis is not known. Wilms tumor

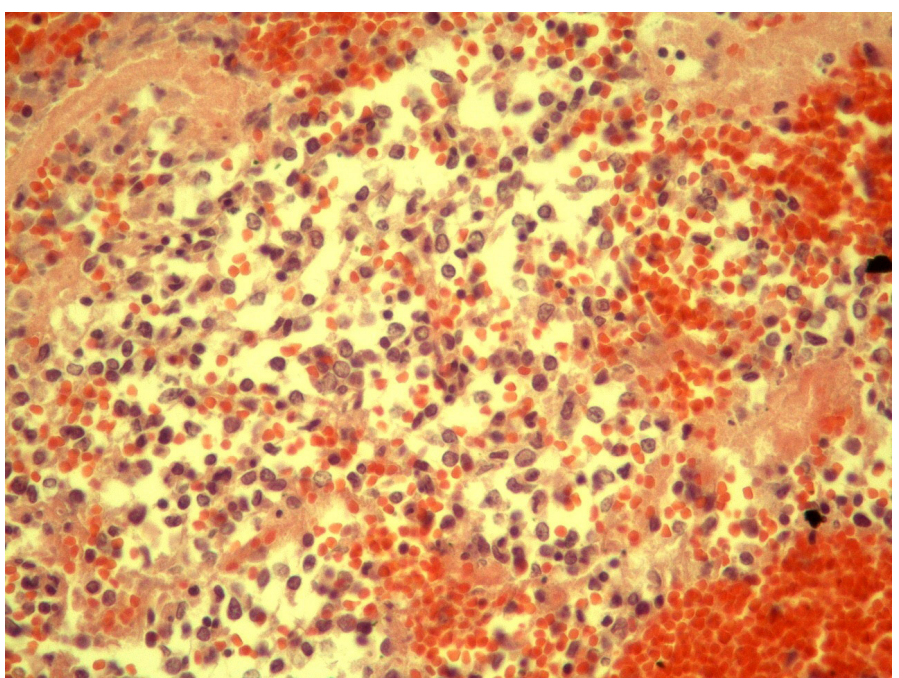

FIGURE 4. The microscopic appearance of clear cell sarcoma composed of epitheloid cells with pale cytoplasm and indistinct nucleoli separated by a clear extracellular matrix (hematoxylin-eosin x400). is bilateral in approximately $5 \%$ of cases, while clear cell sarcoma is almost always unilateral. In some $10 \%$ of cases, overgrowth syndromes, isolated anhidrosis, and congenital anomalies, such as trisomy-18, hypospadias, or cryptorchidism may accompany Wilms tumor. No concomitancy between clear cell sarcoma and the abovementioned anomalies has been reported so far [1,9]. In clear cell sarcoma, the most frequently described anomaly is a loss of the 19 chromosome and a $1 \mathrm{p}$ chromosome gain [10, 11]. Other anomalies that have been demonstrated are rearrangements of the YWHAE gene on chromosome 17 and the FAM22 gene on chromosome 10, dysregulation of epidermal growth factor and overproduction of the Ckit protein $[12,13,14]$. Though a series of chromosomal translocations and genetic changes have been described in clear cell tumors, its molecular pathogenesis and cellular origin have not yet been clarified [4]. The results of karyotypic examination in these cases are generally within normal limits [15].

Histopathologically it is very hard to discriminate a CCSK tumor from other renal tumors. It has similarities to blastomal and stromal Wilms tumor. Typical characteristics of the tumor are a large size with mucinous material, the presence of necrotic foci, and a marked cystic formation. [3]. It consists of small, round, uniform cells containing clear cytoplasm, indistinct nucleoli, abundant extracellular matrix, and evenly distributed fine chromatin separated by a delicate vascular network $[5,16]$. The microscopic appearance of the histopathology slide of our case is shown in Figure 4. As is the case with Wilms tumor, a widely accepted diagnostic immunohistochemical feature of clear cell sarcoma is not available. Diagnostic clues include clearly separated nuclear cavities, a fine chromatin network, and a relatively younger mean patient age [3]. However, as in the present case, rarely, patients may also be older.

In conclusion, the differential diagnosis of clear cell sarcoma and Wilms tumor can be difficult; however, an accurate diagnosis is important for the choice of treatment and prognosis. Clear cell sarcoma should be considered in the differential diagnosis of children with renal masses. It should also not be forgotten that these patients can present with spontaneous bleeding.

Conflict of Interest: No conflict of interest was declared by the authors.

Financial Disclosure: The authors declared that this study has received no financial support. 
Authorship contributions: Concept - Z.C.O., Y.D.K.; Design Z.C.O., O.B., Y.D.K.; Supervision - O.B.; Materials - M.O., M.S.A.; Data collection \&/or processing - B.A., M.O., M.F.A.; Analysis and/or interpretation - Z.C.O., O.B.; Writing - Z.C.O.; Critical review - O.B.

\section{REFERENCES}

1. Malkan AD, Loh A, Bahrami A, Navid F, Coleman J, Green DM, et al. An approach to renal masses in pediatrics. Pediatrics 2015;135:142-58.

2. Zhuge Y, Cheung MC, Yang R, Perez EA, Koniaris LG, Sola JE. Pediatric non-Wilms renal tumors: subtypes, survival, and prognostic indicators. J Surg Res 2010;163:257-63. [CrossRef]

3. Argani P, Perlman EJ, Breslow NE, Browning NG, Green DM, D'Angio GJ, et al. Clear cell sarcoma of the kidney: a review of 351 cases from the National Wilms Tumor Study Group Pathology Center. Am J Surg Pathol. 2000;24:4-18. [CrossRef]

4. Gooskens SL, Furtwängler R, Vujanic GM, Dome JS, Graf N, van den Heuvel-Eibrink MM. Clear cell sarcoma of the kidney: a review. Eur J Cancer 2012;48:2219-26. [CrossRef]

5. Short SS, Zmora O, Hunter CJ, Wang L, Siegel S, Ford HR. Large clear cell sarcoma of the kidney mistaken as Wilms tumor. J Ped Surg Case Reports 2013;1:235-8. [CrossRef]

6. Vasei M, Moch H, Mousavi A, Kajbafzadeh AM, Sauter G. Immunohistochemical profiling of Wilms tumor: a tissue microarray study. Appl Immunohistochem Mol Morphol 2008;16:128-34. [CrossRef]

7. Sebire NJ, Vujanic GM. Paediatric renal tumours: recent developments, new entities and pathological features. Histopathology 2009;54:516-28.

8. Emir S. Wilms tumor with intravascular tumor thrombus. Transl Pediatr 2014;3:29-33.

9. Mullen E, Graf N. Clinical Presentation. In: Pritchhard-Jones K, Dome JS, editors. Renal tumor of childhood. London: Springer-Verlag Berlin Heidaelberg; 2014. p. 39-51. [CrossRef]

10. Schuster AE, Schneider DT, Fritsch MK, Grundy P, Perlman EJ. Genetic and genetic expression analyses of clear cell sarcoma of the kidney. Lab Invest 2003;83:1293-9. [CrossRef]

11. Barnard M, Bayani J, Grant R, Zielenska M, Squire J, Thorner P. Comparative genomic hybridization analysis of clear cell sarcoma of the kidney. Med Pediatr Oncol 2000;34:113-6. [CrossRef]

12. O'Meara E, Stack D, Lee CH, Garvin AJ, Morris T, Argani P, et al. Characterization of the chromosomal translocation $\mathrm{t}(10 ; 17)(\mathrm{q} 22 ; \mathrm{p} 13)$ in clear cell sarcoma of kidney. J Pathol 2012;227:72-80. [CrossRef]

13. Little SE, Bax DA, Rodriguez-Pinilla M, Natrajan R, Messahel B, Pritchard-Jones K, et al. Multifaceted dysregulation of the epidermal growth factor receptor pathway in clear cell sarcoma of the kidney. Clin Cancer Res 2007;13:4360-4. [CrossRef]

14. Jones C, Rodriguez-Pinilla M, Lambros M, Bax D, Messahel B, Vujanic GM, et al. c-KIT overexpression, without gene amplification and mutation, in paediatric renal tumours. J Clin Pathol 2007;60:1226-31.

15. Hadley GP, Sheik-Gafoor MH. Clear cell sarcoma of the kidney in children: experience in a developing country. Pediatr Surg Int 2010;26:345-8.

16. Boo YJ, Fisher JC, Haley MJ, Cowles RA, Kandel JJ, Yamashiro DJ. Vascular characterization of clear cell sarcoma of the kidney in a child: a case report and review. J Pediatr Surg 2009;44:2031-6. [CrossRef] 